\title{
PARADIGMA SOSIALISASI DAN KONTRIBUSINYA TERHADAP PENGEMBANGAN JIWA BERAGAMA ANAK
}

\author{
Anwar \\ Institut Agama Islam Negeri (IAIN) Parepare \\ Email:anwarstain@gmail.com
}

\begin{abstract}
This article examines the social capacities that become the potential of every human being in relation to the development of his religious soul. Humans are known as religious beings, meaning that in a human way humans make statements, agreements to believe in God, and this is a religious potential that needs to be maintained by a healthy and religious environment.

When socializing, every human being is in an environment whose behavior patterns have been formed, and face a norm system that is used as a basis for interaction. Therefore, religious souls need an environment that can direct it to the right direction for growth, that is, the awareness of religion according to what has been pledged while still in the mother's womb.
\end{abstract}

Keywords: Socialization, Social Environment and Religious Souls.

\section{PENDAHULUAN}

Dalam pandangan Islam bahwa sistem sosial, khususnya pola-pola perilaku dalam lingkungan harus menjadi wadah yang subur terhadap perkembangan dan pengembangan segala potensi anak, termasuk potensi keagamaan. Proses pematangan potensi menuju tingkat perwujudan yang maksimal merupakan hasil interaksi yang efektif antara potensi bawaan dengan lingkungan sosial. Untuk itu dibutuhkan pola-pola sinergitas dan korelasional di antara keduanya. ${ }^{1}$ Watak manusia merupakan hasil perpaduan dan interaksi antara bakat tabi'i atau fitrah (faktor internal) yang diwariskan dari orangtua, dan faktor dari luar yang berasal dari unit-unit sosial, sebagai inti unit sosial adalah keluarga. ${ }^{2}$ Jika di antara keduanya (lingkungan dan potensi bawaan) tidak

${ }^{1}$ Hasan Langgung, Teori-Teori Kesehatan Mental, Cet.I; (Jakarta: Pustaka Al-Husna, 1979), h. 141-143

${ }^{2}$ Omar Mohammad Al-Toumy Al-Syaibany, Falsafatut Tarbiyah Al-Islamiyah, diterjemahkan oleh Hasan Langgulung, dengan judul "Falsafah Pendidikan Islam", Cet. I; ( Jakarta: Bulan Bintang, 1979), h. 138 
memberikan relasi pengaruh positif, maka dampak negatifnya terlihat pada perkembangan dan kematangan potensi anak.

Lingkungan sebagai faktor eksternal berperan memberikan kontribusi dalam hal pengalaman dan pendidikan yang dibutuhkan oleh anak. Karenanya menjadi tanggung jawab moral bagi para orang dewasa untuk menyiapkan lingkungan yang dapat memenuhi kebutuhan psikis dan kebutuhan edukatif bagi anak. Kebutuhan psikhis adalah aspek kondisional yang terkait dengan emosi, mental, kognitif yang sifatnya dapat berfungsi dalam menggugah kesadaran beragama. Sebab pengembangan potensi keberagamaan pada prinsipnya merupakan proses kejiwaan dalam memotivasi anak untuk bersikap normatif dalam mematuhi dan mentaati aturan agama.

Kebutuhan pendidikan adalah adalah aspek edukatif yang didapatkan oleh anak ketika bersosialisasi. Anak dalam sosialisasinya seringkali menghadapi kenyataan lingkungan yang kurang memberikan dukungan terhadap perkembangan jiwa keagamaannya. Para orang dewasa mengabaikan peran imitasi dan identifikasi sebagai sesuatu yang amat penting dalam proses perkembangan anak. Peran imitasi dan identifikasi membutuhkan pribadi orang dewasa, secara khusus orangtua, memiliki kualitas ketokohan secara moral dan agama. Jika hal ini terabaikan, maka memberikan peluang kepada anak untuk melakukan imitasi dan identifikasi pada subyek lain, secara moral dan agama tidak layak dijadikan figur ketokohan.

Pada saat anak bersosialisasi dengan lingungannya, anak menempatkan dirinya dalam posisi sebagai subyek mencari nilai-nilai edukatif. Ketika nilai-nilai edukatif itu tidak dijumpai di lingkungan sosialnya, maka ia akan memilih refrensi lain sebagai sumber nilai dalam pembentukan jiwa keagamaannya.

Proses edukasi pematangan jiwa keagamaan terjadi karena adanya pengaruh yang dominan dari lingkungan. Gejala di lingkungan sosial menjadi corak, model, yang menentukan arah dari pola perkembangan jiwa keagamaan anak. Jika corak, dan model pengaruh lingkungan cenderung memberikan warna negatif bagi sosialisasi anak maka terbentuk pola perkembangan jiwa keagamaan 
yang tidak sehat, sebaliknya jika warna positif lingkungan yang dominan maka terbentuk pola perkembangan jiwa keagamaan yang sehat.

Atas dasar itu, dapat ditegaskan bahwa sosialisasi dapat memberi corak, warna dan model perkembangan jiwa keagamaan anak. Untuk itu, sosialisasi anak perlu direspon dengan penciptaan kondisi lingkungan yang edukatif dan agamais.

\section{PEMBAHASAN}

\section{Arti Sosialisasi, dan Jiwa Beragama}

\section{Sosialisasi}

Sosialisasi mengisyaratkan suatu makna di mana setiap individu berupaya menyelaraskan hidupnya di tengah-tengah masyarakat. Dalam sosialisasi, seseorang akan mengenal dan melakukan penyesuaian dengan keadaan tempat dia bersosialisasi. Lewat proses sosialisasi, individu-individu masyarakat belajar mengetahui dan memahami tingkah laku pekerti apakah yang harus dilakukan, dan tingkah laku pekerti apakah yang harus tidak dilakukan. ${ }^{3}$ Hal seperti itu, dikemukakan oleh Abdul Syani, bahwa sosialisasi adalah proses belajar yang dilakukan oleh individu untuk berbuat atau bertingkah laku berdasarkan patokan yang terdapat dan diakui dalam masyarakat disekitarnya. ${ }^{4}$

Menurut Soejono Dirjosisworo, sebagaimana dikutip oleh Abdul Syani, bahwa sosialisasi terdiri atas aktivitas, yaitu;

a. Proses sosialisasi adalah proses belajar, yaitu suatu proses akomodasi dengan mana individu menahan, mengubah impuls-impuls dalam dirinya dan mengambil alih cara hidup atau kebudayaan masyarakat.

b. Dalam proses sosialisasi itu individu mempelajari kebiasaan, sikap, ideide, pola nilai-nilai dan tingkah laku di dalam masyarakat dimana ia hidup.

\footnotetext{
${ }^{3}$ J. Dwi Narwako, dan Bagong Suyanto, Sosiologi Teks Pengantar dan Terapan, Edisi Kedua, Cet. III., ( Jakarta: Prenada Media Group, 2007). h. 74

${ }^{4}$ Abdul Syani, Sosiologi Skematika, Teori dan Terapan, Cet. III; (Jakarta: Bumi Aksara, 2007),h. 57
} 
c. Semua sifat dan kecakapan yang dipelajari dalam proses sosialisasi itu disusun dan dikembangkan sebagai suatu kesatuan sistem dalam diri pribadinya. 5

Dari pandangan di atas, dapat dipahami bahwa ketika anak bersosialisasi pada dasarnya melakukan pengenalan, penghayatan, terhadap norma-norma dan nilai di lingkungan sekitarnya. Suatu proses yang dapat memberikan nilai-nilai yang dibutuhkan terhadap pembentukan sikap dan kepribadian. Dalam sosialisasi, seseorang dituntut agar dapat menyesuaikan diri dengan pola-pola perilaku orangorang di sekitarnya. Penyesuaian hal yang demikian itu, mencakup aspek yang luas seperti kebiasaan, sikap, ide-ide, pola hubungan sosial, serta nilai dan tingkah laku.

Beragam hal yang mungkin ditemui oleh anak ketika bersosialisasi. Di lingkungan keluarga, anak akan pasti menemukan tradisi keagamaan yang dikembangkan di dalamnya, di samping itu dijumpai pula adanya pola-pola perilaku dan relasi yang terbentuk di lingkungan keluarga. Meskipun pola sosialisasi di lingkungan keluarga sangat terbatas dan coraknya face to face di antara sesama anggota kelurga, namun sumbangsihnya adalah sangat bagi kehidupan anak pada periode selanjutnya. Karena tahap sosialisasi ini, merupakan fundasi yang dapat menjadi dasar pembentukan diri pribadi anak. Di lingkungan sekolah, anak akan pasti berinteraksi dengan pola-pola perilaku yang beragam dilatari dengan budaya, suku, bahasa, dan agama yang berbeda. Hal ini menunjukkan bahwa sosialisasi di lingkungan sekolah, anak akan menemukan corak karakter teman dan gurunya yang begitu variatif.

\section{Jiwa Beragama}

Manusia adalah homo religious (makhluk beragama), artinya manusia mempunyai potensi beragama. ${ }^{6}$ Beberapa istilah yang sering digunakan untuk menjelaskan arti jiwa keagamaan, seperti instink bergama, naluri beragama, perasaan beragama, dan fitrah beragama. Pada dasarnya istilah tersebut menjadi

\footnotetext{
${ }^{5}$ Ibid. h. 57

${ }^{6}$ Jalaluddin, Psikologi Agama, Cet. VI; ( Jakarta: Raja Grafindo, 2002), h. 198
} 
bukti bahwa manusia secara kodrati dibekali kecenderungan beragama, sebagai salah satu potensi bawaan sejak lahir.

Jiwa keagamaan merupakan terminologi yang sering dipakai dalam ilmu jiwa agama. Konsep ini menunjukkan bahwa setiap individu mempunyai motifmotif keagamaan sebagai potensi laten, dibawa sejak lahir, dimana proses dan pengembangannya dimodifikasi oleh lingkungan. Dalam peristilahan lain, sesuai terminologi al-Qur'an, diartikan sebagai fitrah. Al-Qur'an mempergunakan kata fathir untuk memberi pengertian sang Pencipta, atau kata fathara yang menunjuk kepada arti makhluk yang diciptakan. Sementara pada ayat lain, kata fithrah memberikan penegasan makna agama $(\text { ad-dien })^{7}$

Lafadz fatharah (M. Quraisy Shihab) istilah yang memberi arti penciptaan sesuatu dari tiada menjadi ada. Penciptaan manusia disertai dengan fitrahnya, sebagai sifat hakiki yang tidak berubah. Dari segi terminologi; fitrah (ar-Rum ayat 30, dan Hadits Nabi), menurut Hasan Langgulung, mempunyai dua arti; (1) potensi dan sifat naluri (pembawaan) manusia atau sifat-sifat Tuhan yang menjadi potensi manusia sejak lahir, (2) wahyu Tuhan (ad-Dien) sesuai dengan fitrah manusia. $^{8} \quad$ Oleh Abdurrahman Saleh Abdullah, menyebut bahwa fitrah adalah kecenderungan beragama tauhid atau Islam, juga berarti agama Islam adalah agama fitrah. ${ }^{9}$ Menurut Ahmad Hatta, bahwa fithrah adalah maksudnya ciptaan Allah Swt. Manusia diciptakan oleh Allah mempunyai naluri beragama yaitu agama tauhid. Kalau ada manusia tidak beragama tauhid, maka hal itu tidaklah wajar. ${ }^{10}$

Substansi kecenderungan beragama (fitrah), bersifat kodrati dinyatakan, diikrarkan oleh seorang hamba untuk beragama tauhid ketika manusia dalam periode pada alam rahim ibunya. ${ }^{11}$ Perjanjian yang mengikat keyakinan tentang

${ }^{7}$ Abd. Rahman Shaleh, Educational Theory: a Qur'anic Outlook, diterjemahkan oleh M. Arifin, dan Zainuddin, dengan judul “ Teori-Teori Pendidikan Berdasarkan Al-Qur'an”, Cet.I; (Jakarta: Rineka Cipta, 1990 ),h. 56-57

${ }^{8}$ Hasan Langgulung, Manusia dan Pendidikan Suatu Analisa Psikologi dan Pendidikan, Cet. II; ( Jakarta: Pustaka Al Husna, 1989 ), h.3-9

${ }^{9}$ Abd. Rahman Shaleh Abdullah, Op. cit., h. 59-60

${ }^{10}$ Ahmad Hatta, Tafsir Qur'an Perkata Dilengkapi dengan Asbabun Nuzul dan Terjemah, (Cet. I; Jakarta: Maghfirah Pustaka, 2006), h. 40

${ }^{11}$ Al-Qur'an Surah Al-A'raf (17) ayat172. Terjemahnya" Dan ingatlah ketika Tuhanmu mengeluarkan keturunan anak Adam dari sulbi mereka dan Allah mengambil kesaksian kepada jiwa mereka (seraya) berfirman: Bukankah Aku ini Tuhan-mu ?. Mereka menjawab: Betul (sesungguhnya Engkau adalah Tuhan kami), kami menjadi saksi agar pada hari kiamat engkau tidak mengatakan: sesungguhnya kami tidak pernah diberi peringatan (terhadap ke-Esaan Allah). 
Keesaan Allah Swt., agar tidak berpandangan di luar garis ketetapan Allah Swt. Perjanjian itu adalah bentuk komitmen seorang hamba agar menjauhi faham yang dapat mereduksi keyakinan tauhid, misalnya faham animisme, dinamisme, politeisme, dan faham panteisme.

Para ahli secara ilmiah telah membuktikan bahwa keberagamaan merupakan potensi kodrati yang ada pada setiap manusia. Seperti penyataan pandangan Afif. At-Tabbarah. "Faith in the existence of God is a natural disposition in man and a necessity, in this regard, to the acquire it throught intellectual maturaty... The most significant is that religiousness is a common tendency in all human beings, both ancient and modern." ${ }^{2}$ Fitrah beragama merupakan kecenderungan alami yang dimiliki oleh setiap manusia dan sebagai suatu kebutuhan. Dalam perkembangannya memerlukan kematangan intelektual. Hal yang paling penting bahwa keberagamaan adalah merupakan kecenderungan umum pada semua makhluk manusia, baik pada masyarakat maupun masyarakat moderen.

Cressy Morriosn; "as a metter of fact that every man is born in harmony with nature. The many fact that every man since his creation is born with nature. Man's appeal to the Creator is one of indicate that religion is innate in him.",13 Suatu fakta yang tidak dapat dipungkiri bahwa setiap manusia lahir dengan sifat asalnya. Banyak fakta yang menunjukkan bahwa setiap manusia sejak dia diciptakan lahir dengan sifat asalnya. Pujian-pujian yang diwujudkan manusia terhadap Tuhan Pencipta merupakan salah satu indikasi bahwa agama merupakan bawaan di dalam dirinya.

Sementara itu, Hasan Langgung memandang bahwa fitrah bergama merupakan perjanjian ketuhanan oleh manusia yang akan mengikatnya dalam kehidupannya di diunia ini. ${ }^{14}$

\section{Sosialisasi: Persentuhan Nilai-nilai Keagamaan}

Proses sosialisasi adalah upaya seseorang mengenal, menyesuaikan, dan mentransmisikan nilai-nilai di mana ia hidup sehingga dengan penyerapan nilainilai yang ada menjadi kekuatan normatif terhadap pembentukan kepribadian.

\footnotetext{
${ }^{12}$ Afif at-Tabbarah, The Spirit of Islam Doctrin and Teachings, Edisi I; (London, 1993 ), h. 18

${ }^{13}$ Afif at-Tabbarah, Op cit., h.19

${ }^{14}$ Hasan Langgulung, Op cit., h.7
} 
Sosialisasi pertama dan utama berlangsung di lingkungan keluarga. Meskipun keluarga disebut sebagai unit terkecil dalam sistem sosial dan relasi hubungan sosial yang terjadi di dalamnya berlangsung secara face to face, namun posisi dan eksistensinya merupakan institusi yang elementer peranannya. Keluarga sebagai lembaga sosialisasi membutuhkan peran yang tepat dan efektif dari orangtua dalam rangka untuk mewujudkan fungsi psikologi dan keagamaannya. Hal ini penting, mengingat orangtua merupakan tokoh yang pertama yang dapat mentransmisi nilai-nilai keagamaan kepada anak. Selain itu, orangtua harus pula menciptakan pola-pola perilaku yang dapat menciptakan suasana psikologi yang aman bagi anak-anaknya.

Persentuhan nilai-nilai keagamaan dengan sikap dan kepribadian anak di lingkungan sekitar, melalui tiga cara yaitu (1) anak mengakomodasi segala suasana di luar dirinya dengan jalan mengubah impuls-impuls dalam dirinya dan menyesuaikannya dengan cara hidup dengan orang-orang yang ada disekitarnya, (2) anak mempelajari dan menyerap segenap pola-pola perilaku dan nilai-nilai serta sikap kepatuhan dari apa yang menjadi tingkah laku dan dipraktikkan dalam masyarakat, (3) anak menjadikan seluruh pola perilaku dan nilai yang diserap di dalam masyarakat sebagai suatu kesatuan sistem dalam pribadinya.

Jadi lingkungan sekitar merupakan ruang bagi anak untuk memperkaya khasanah nilai-nilai kepribadiannya. Karenanya, ketika anak bersosialisasi maka lingkungan itu harus menjadi kondisi yang steril dari unsur-unsur yang dapat berfungsi sebagai virus yang merusak kepribadiannya. Dengan kata lain, lingkungan harus sebagai lahan yang dapat menyuburkan jiwa keagamaan anak. Adapun syarat dari suatu lingkungan yang sehat bagi anak, adalah;

a. Suasana yang ditata yang menggambarkan iklim edukatif dan agamais sebagai upaya untuk memenuhi kebutuhan psikhis keagamaan anak agar terarah pada kondisi-kondisi positif.

b. Pola-pola perilaku yang tercipta di dalamnya, adalah manifestasi atas keyakinan dan kesadaran keagamaan .

c. Unit-unit sosial merupakan ruang lingkup interaksi yang norma dan sistemnya mempengaruhi anak ke arah perkembangan dan kematangan yang stabil. 


\section{Pola Perilaku: Suasana Perkembangan Jiwa Beragama}

Pola-pola perilaku yang lazim dijumpai dan dihadapi ketika terjadi sosialisasi menggambarkan situasi yang beragam dan karakteristik. Pada intinya dapat dikelompokkan ke dalam, yaitu (1) pola perilaku dalam hubunganhubungan sosial antara individu dengan individu, (2) pola perilaku dalam hubungan individu dengan kelompok, dan (3) pola perilaku dalam hubungan kelompok dengan kelompok. Begitu halnya jika dilihat dari pola perilaku yang terdapat pada lembaga-lembaga pendidikan. Situasi dan karakteristik di lingkungan keluarga (in formal) sudah pasti berbeda dengan situasi yang dialami oleh anak di lingkungan sekolah (formal).

Meskipun demikian, perbedaan dan karakteristik pola perilaku itu tetap senantiasa berdasar pada norma-norma yang diakui. Pola perilaku itu diatur dengan norma-norma yang ada sebagai hasil konsensus. Di lingkungan keluarga, norma-norma yang dipraktekkan adalah kebiasaan atau tradisi yang diwariskan bersumber dari ajaran agama, faham keyakinan, dan nilai-nilai sosial budaya. Di lingkungan sekolah, adalah anak bersentuhan dengan tradisi dan budaya sekolah dengan sistem pengaturan yang ketat, disertai dengan proses perencanaan dan pembelajaran secara formal.

Melalui proses sosialisasi, seorang individu menjumpai pola-pola perilaku yang secara umum dikelompokkan ke dalam dua bagian, yaitu;

1. Proses sosialisasi yang dikerjakan ( tanpa sengaja ) lewat proses interaksi social; dan

2. Proses sosialisasi yang dikerjakan (secara sengaja) lewat proses pendidikan dan pengajaran. ${ }^{15}$

Sosialisasi yang menunjukkan pola-pola perilaku yang tidak sengaja terjadi ketika individu berinteraksi melakukan tindakan peniruan, imitasi, terhadap apa-apa yang disaksikan dari perilaku pekerti dari orang-orang disekitarnya. Selanjutnya apa yang disaksikan itu, mengalami penginternalisasian ke dalam diri dan mental terhadap pola-pola perilaku dan norma-norma yang ada.

Ketika terjadi proses sosialisasi, maka seorang anak menghadapi situasi lingkungan sosial yang di dalamnya telah terbentuk pola-pola perilaku, sikap, dan juga norma-norma yang ada yang selalu dijadikan acuan atau dijadikan standar berperilaku. Di lingkungan sosial, anak memperoleh pengamalan baru dan

${ }^{15}$ J. Dwi Narwako, dan Bagong Suyanto, Op. cit.h., 86 
melakukan proses pembelajaran, sekaligus menghadapi persoalan, yaitu elemenelemen negatif yang ada di lingkungan pergaulan.

Proses Sosialisasi melibatkan komponen individual berupa kemampuan, fasilitas kecakapan mental atau psikologi seseorang, misalnya potensi kapasitas belajar untuk beradaptasi dan merespon situasi organisme di lingkungan sekitar. Keterlibatan aspek-aspek fisis-biologi secara serta merta juga melibatkan psikis dan mental anak. Aspek yang ke dua ini, dapat dikatakan sebagai faktor penentu terjadinya proses pembelajaran dan pemindahan pengalaman serta nilai-nilai pada diri anak. 
Clerence C. Schreg, dkk, mengemukakan paradigma dalam proses sosialisasi ${ }^{16}$, sebagai berikut:

\section{Paradigm of Socialization Process}
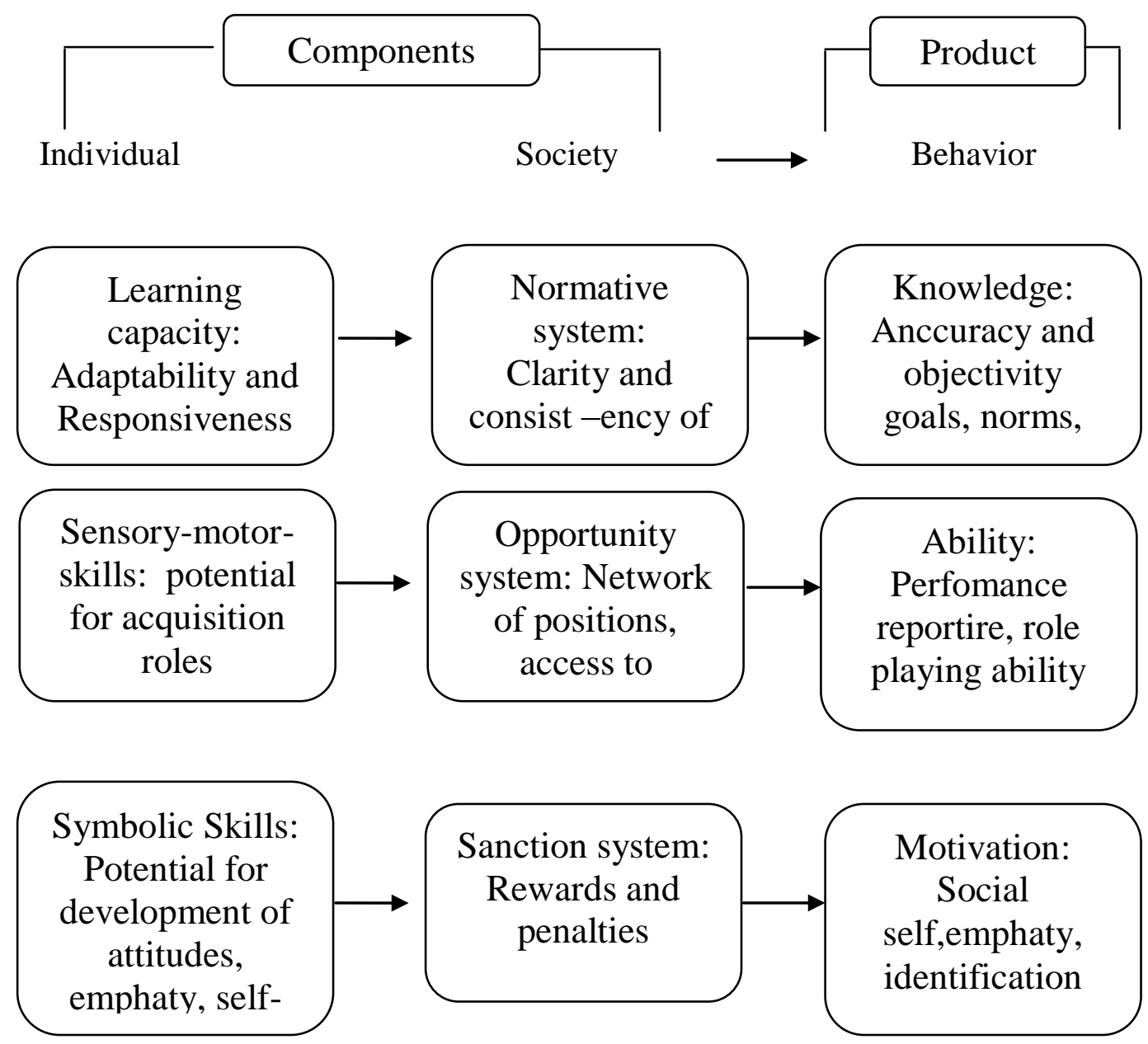

Paradigma sosialisasi di atas menunjukkan bahwa komponen sosialisasi terdiri atas (1) individu dan (2) masyarakat. Dari aspek individu bahwa setiap orang mempunyai kapasistas belajar di lingkungannya, keterampilan motorsensorik, dan keterampilan simbolik. Dari aspek masyarakat, mempunyai tiga elemen sistem, yaitu (1) sistem norma, (2) sistem kesempatan, dan (3) sistem sanksi. Antara komponen-komponen individual berupa kapasitas, adaptabilitas, keterampilan motorik sensorik, dan keterampilan simbolik dengan komponen

${ }^{16}$ Clerence C. Schreg, Otto N. Lorsen, and William B. Cattom, Sociology Fourth Edition, (USA: Harper and Rpw Publishers, t.th ), h. 280 
masyarakat berupa sistem norma, kesempatan dan sistem sanksi merupakan dua komponen yang mesti terdapat dalam sosialisasi, dari hasil interaksi antara keduanya mewujudkan pola-pola perilaku seperti pengetahuan, kemampuan dan motivasi.

Ketika bersosialisasi, seorang anak menghadapi pola-pola perilaku di dalam lingkungan sosialnya. Sebagai makhluk individu, dia mempunyai kemampuan untuk beradaptasi, melakukan proses belajar, merespon keadaan di sekitarnya, sebagai instrumen psikologi untuk dapat mengembangkan kecakapan motorik dan kecakapan simbolik, dimana kecakapan simbolik merupakan potensi yang diperlukan dalam mengembangkan sikap, rasa empati dan konsep diri.

Kapasitas yang bersifat individual ini mengalami proses kematangan ke arah yang tepat jika dipengaruhi oleh sistem norma-norma dalam lingkungan social, diparaktekkan dan diwujudkan sebagai kepribadian sosial. Anak yang dalam proses pertumbuhan dan perkembangan jiwa keagamaannya tidak dapat dipisahkan dengan sistem norma sosial dan kepribadian sosial yang dibentuk oleh sistem norma sosial, di antaranya sistem norma agama.

Sistem norma agama yang sumbernya dari doktrin agama atau keyakinan agama, jika itu menguat sebagai norma utama dalam interaksi sosial, diwujudkan sebagai aturan dan kaedah dalam pergaulan, maka anak akan hidup dan berkembang dalam kondisi sosial yang sehat. Sebab faktor kesadaran sosial untuk berpijak pada landasan normatif agama akan menjadi lingkungan eksternal yang potensial terhadap arah perkembangan jiwa keagamaan anak.

Anak pada pada dasarnya memerlukan faktor lingkungan yang dapat mengarahkan proses kearah mana jiwa keagamaanya berlabu. Tentu saja keadaan lingkungan yang memungkinkan hal itu adalah perwujudan pola-pola perilaku orang di lingkungan sosial yang dijiwai dan didasari dengan norma agama. Keadaan lingkungan sekitar yang demikian, adalah keadaan lingkungan yang sehat dan normatif serta religious. 


\section{PENUTUP}

\section{Kesimpulan}

1. Manusia adalah makhluk yang membawa potensi jiwa keagamaan, sebagai suatu sifat alamiah-kodrati. Kecenderungan beragama, dalam terminologi Islam, disebut dengan fitrah. Fitrah beragama merupakan ikrar untuk beragama tauhid sebagai modal ketuhanan yang di bawah sejak lahir.

2. Manusia mempunyai kapasitas diri yang dapat dijadikan sebagai alat atau media untuk bersosialisasi, disamping kapasitas sebagai makhluk sosial, juga mempunyai kemampuan responsif, sikap, dan empati, dan kesadaran diri dengan orang lain. Kapasistas tersebut menjadi kekuatan yang sifatnya individual dan keperluan untuk bersosialisasi ketika melakukan interaksi sosial.

3. Potensi jiwa keagamaan yang didukung dengan kapasiatas diri untuk berinteraksi sosial, menjadi modal utama untuk menjaga konsistensi ikrar manusia (jiwa keagamaannya) agar tetap berada pada jalur keyakinannya sesuai doktrin agama. Di lingkungan sosial, setiap anak menghadapi polapola perilaku yang dibentuk oleh norma-norma yang ada, maka yang paling utama adalah pola-pola perilaku yang dijiwai dan dilandasi oleh norma agama, yang sifatnya religious.

\section{DAFTAR PUSTAKA}

Al-Toumy Al-Syaibany, Oemar Mohammad,1979. Falsafatut Tarbiyah AlIslamiyah, diterjemahkan oleh Hasan Langgulung, dengan judul "Falsafah Pendidikan Islam”, (Cet. I; Jakarta: Bulan Bintang)

At-Tabbarah, Afif, 1993. The Spirit of Islam Doctrin and Teachings, Edisi I; (London)

C. Schreg, Clerence, Otto N. Lorsen, and William B. Cattom, Sociology Fourth Edition, (USA: Harper and Rpw Publishers, t.th ).

Departemen Agama RI, 2013. AlQur'an dan Terjemahnya, ( Yayasan Penyelenggara Penterjemah dan Pentafsih Al Qur'an Kerjasama dengan Pemerintah Kerajaan Arab Saudi) 
Hatta, Ahmad, 2006. Tafsir Qur'an Perkata Dilengkapi dengan Asbabun Nuzul dan Terjemah, (Cet. I; Jakarta: Maghfirah Pustaka)

Jalaluddin, Psikologi Agama, 2002. ( Cet. VI; Jakarta: Raja Grafindo)

Langgung, Hasan, 1979. Teori-Teori Kesehatan Mental, ( Cet.I; Jakarta: Pustaka Al-Husna)

Langgulung, Hasan, 1989. Manusia dan Pendidikan Suatu Analisa Psikologi dan Pendidikan, (Cet. II; Jakarta: Pustaka Al Husna)

Narwako, J. Dwi dan Bagong Suyanto, 2007. Sosiologi Teks Pengantar dan Terapan, Edisi Kedua, ( Cet. III; Jakarta: Prenada Media Group)

Abd. Rahman Shaleh, 1990. Educational Theory: a Qur'anic Outlook, diterjemahkan oleh M. Arifin, dan Zainuddin, dengan judul " Teori-Teori Pendidikan Berdasarkan Al-Qur'an”, ( Cet.I; Jakarta: Rineka Cipta )

Syani, Abdul, 2007. Sosiologi Skematika, Teori dan Terapan, ( Cet. III; (Jakarta: Bumi Aksara) 